\title{
Debate
}

Olivia Killias, Marina de Regt, Johan Lindquist and Rebecca Elmhirst

Olivia Killias, (2018). Follow the maid: Domestic worker migration in and from Indonesia. Copenhagen: NIAs Press.

\section{Temporality and Transitions}

International migration of Indonesian women as domestics has become an almost structural aspect of Indonesian society, with implications on many different social, economic, and political levels. In the past two decades, Indonesian women have gradually replaced Filipinas, who were for a long time seen as the 'quintessential domestic worker' (Parreñas 2001), a development which I also observed during my own research on migrant domestic workers in Yemen (see De Regt 2008). Inspired by the ways in which the Philippines turned international migration into an economic asset, the Indonesian government started promoting migration via programmes and policies in the last two decades. As a result, millions of women have migrated abroad, to Malaysia, Hongkong, Singapore, the Gulf States, and Saudi Arabia, to mention just a few destinations. Nicole Constable even republished her seminal work Maid to order in Hongkong in 2007 with additional data about Indonesian women. As a result, an increasing number of publications about Indonesians domestic workers have seen the light. Olivia Killias's ethnography Follow the maid: Domestic worker migration in and from Indonesia (2018) is, however, the first book-length study about the topic and therefore a very welcome addition to the already existing literature. Moreover, Killias's study spans more than a decade and therefore provides new insights in the spatial and temporal dimensions of migrant domestic work.

Started as a $\mathrm{PhD}$ project in 2006 in a Javanese village, Killias has regularly returned to Indonesia and Malaysia and, in doing so, was able to collect longitudinal data over a period of ten years. The title of her book refers to the fact that she has literally followed Indonesian women from the village to the training camp in Jakarta, and from there to Malaysia and back to the village. Very few other studies on migrants, and on domestic workers in particular, are 
based on such extensive, multi-sited fieldwork in both the country of origin and the country of migration. Moreover, Killias frames her research findings within the most important theoretical discussions about gender and migration, and migrant domestic work in particular, but also more broadly in debates about globalization, mobility, and social change. She argues that Indonesian women are turned into maids (a term which is seen as rather derogatory in the literature on domestic workers) through moral, social, economic, and legal processes in and outside Indonesia but also shows the intricate ways in which women negotiate their new identities and struggle to make the best of their new lives.

Killias's focus on the process of migration means that she pays ample attention to temporality. Time plays a crucial role in many phases of women's migration trajectories, defining for example the moment that women are allowed to migrate abroad and the time they can return home. According to Killias, almost all international migration for domestic work is organized by recruitment agencies and based on two-year contracts. The migration of women is therefore always temporary. Killias rightly links these temporalities to women's life courses as well (Killias uses the term life cycle, which leaves less space for the fluidity of life stages; see Johnson Hanks 2002). To start with, only married women older than 21 years can legally migrate overseas according to Indonesian government policies. Younger and unmarried women often first migrate to Jakarta and only later internationally. Killias mentions that internal migration is increasingly seen as a rite of passage (merantau) for young women, a transition to female adulthood, while historically this term was only used for male migration (p. 72). Marriage is, however, indispensable to come to full adulthood in Indonesia (p. 72). This is an interesting development which makes me think of my own research about Ethiopian women migrants. Similar to Indonesia, international migration of Ethiopian women for domestic work has increased tremendously in the past few decades. While rural-urban migration of girls and young women was historically rather common, nowadays many young women migrate to the Middle East, in particular to Saudi Arabia, the Gulf States, and Lebanon, to take up paid domestic work. In Ethiopia only women over 18 years old are allowed to migrate abroad, but there are many ways in which recruitment agencies and women themselves circumvent the rules. At the end of her book, Killias mentions that young and unmarried women are nowadays also migrating abroad, which is comparable to the situation in Ethiopia, where the majority of female migrants are unmarried, also those who migrate via legal channels. These women often become the main breadwinners for their families, extend their stay abroad, and marry later or not at all. Migration thus affects young women's transition into adulthood. Yet, migra- 
tion can also offer alternative ways of becoming an adult, for example by being economically independent. In our research among adolescent migrant girls in Ethiopia, Sudan, and Bangladesh, we found that economic independence was valued highly by the interviewed girls (see Grabska, De Regt, and Del Franco 2019). While young, unmarried women might still be perceived as adolescents by their families back home, they had acquired adult identities in the places of migration. To what extent are similar processes taking place in Indonesia? In which ways is migration intersecting with other important transitions in women's lives? And which alternative trajectories into adulthood have come into being?

This brings me to another issue related to temporality and the life courses of migrant women, namely the post-migration phase. Killias mentions that women over 35 often return home as they are not allowed to work abroad anymore. What happens to women who have been overseas domestic workers and return home? What is their social status? And more importantly, what are these women going to do after having worked overseas? Their return must have major implications for their own lives and those of their families. The social status of migrant women who have lived in 'Arab countries' is rather low in Ethiopia, which is due to the fact that they have lived abroad without the protection of their relatives and are oftentimes suspected of having had sexual relations, voluntarily or against their will, and are therefore seen as 'loose' women. Many women who returned to Ethiopia after having worked for years in the Middle East thus aspire to migrate again. Killias refers to Claudia Liebelt's study (2008) on Filipinas in Israel, which states that most women 'move on and on' instead of returning and staying home. In the area around the village that Killias studied, women migrated to other countries than Malaysia. To what extent does context matter? Were the experiences of women who went to other destinations similar to those who went to Malaysia? Malaysia is geographically, culturally, and linguistically much closer to Indonesia than the Middle East, for example. Killias refers a few times to people who migrated to Saudi Arabia, but a stronger emphasis on the importance of the local context of Malaysia would have been useful.

\author{
Marina de Regt \\ Vrije Universiteit Amsterdam, Amsterdam, The Netherlands \\ m.c.de.regt@vu.nl
}




\section{References}

Constable, N. (2007). Maid to order in Hongkong: Stories of migrant workers. New York: Cornell University Press.

Grabska, K., M. de Regt, and N. Del Franco (2019). Adolescent girls' migration in the Global South: Transitions into adulthood. New York: Palgrave Macmillan.

Johnson-Hanks, J. (2002). 'On the limits of life stages in ethnography: Toward a theory of vital conjunctures', American Anthropologist, 104-3:865-88o.

Liebelt, C. (2008). 'On sentimental Orientalists, Christian Zionists, and working class cosmopolitans: Filipina domestic workers' journeys to Israel and beyond', Critical Asian Studies 40-4:567-86.

Parreñas, R.S. (2001). Servants of globalization: Women, migration and domestic work. Stanford: Stanford University Press.

Regt, M. de (2008). 'High in the hierarchy, rich in diversity: Asian domestic workers, their networks, and employers' preferences in Yemen', Critical Asian Studies 404:587-6o8.

\section{Thinking with the Maid}

During the past decade, I have followed Olivia's scholarship closely as it has evolved from early articles into a doctoral dissertation and, finally, this excellent monograph. Her work is arguably part of a broader scholarly movement that is concerned with approaching migration as a social and material process that evolves through time and across space and is best described in ethnographic terms. This is reflected in an emerging literature that deals with themes such as the migration industry (Gammeltoft-Hansen and Sørensen 2013), brokers (Lindquist, Xiang, and Yeoh 2012), infrastructure (Xiang and Lindquist 2014), logistics (Altenried et al. 2018), and viapolitics (Walters 2015). Follow the maid adds to, and develops, this literature by retaining a focus on how Indonesian villagers are transformed into domestic workers in a process in which they are recruited, trained, transported, employed, and returned. This creates a productive empirical and analytical space that approaches migration as a brokered process embedded in a range of different environments, rather than focusing strictly on the experiences of migrants or the regulation of migration-in an important sense, the book inhabits the space between. This allows us to understand how women become indebted, controlled, subjugated, but also empowered along the way.

With this in mind, I would like to take the opportunity to raise a couple of broad, interconnected questions. First, how do we understand the Indone- 
sian case that emerged through this description in comparative terms? With regard to this question, there are at least three striking issues, all evident in Olivia's book. On the one hand, the historical importance of private recruitment brokers across Asia has been widely noted (McKeown 2008). This appears particularly evident in Indonesia, however, where multiple levels or chains of brokers are critical at all stages of the migration process, beginning with the intimate relations established at the village level. The sheer number of brokers involved in migration is extraordinary. On the other hand, the Indonesian state is heavily involved in regulating the deployment of low-skilled temporary labour migrants. While the Philippines has generally been considered the clearest example of a 'labor brokerage state' (Rodriguez 2010), the Indonesian state's regulation of migrant mobility seems unprecedented in terms of the attempt to control even the most minute details of the migration process. This is clear in the extensive demands for documentation in the recruitment process, ranging from letters of permission at the village level to health certificates to special migrant passports. Most notably, up until a few years ago, a special return-migrant terminal at the international airport in Jakarta, as well as a few other cities throughout the country, received and escorted returning migrants to their home villages (Kloppenburg 2013). Finally, the gendered dimensions of the migration process are integral both to private brokerage and state regulation. In contrast to men, women are required to receive a letter of permission from their parents or husband in order to depart, have to enter into different forms of debt relations, must take part in more extensive training programmes, and are compelled to pass through a regulated process of return. While other major domestic-worker-sending countries such as the Philippines and Sri Lanka regulate migration in gendered terms, in this regard Indonesia again appears as an extreme case, as the intimate details that characterize the gendered organization of migration across the state-market divide appear unprecedented in comparative terms.

In light of this, allow me to develop a more specific set of questions. If my description of contemporary Indonesian migration rings true, how are we to understand this? Why has a form of migration emerged in Indonesia that to such a significant degree is based on intimate gender-specific forms of recruitment and regulation? What does this tell us about Indonesia and its history? Furthermore, what does this reveal about Indonesian migration compared to other sending countries, and about international domestic-worker migration more generally? Is Indonesian migration an outlier or in fact an exemplary model for the international domestic-worker migration regime? These are admittedly broad questions, but ones that Olivia is well-positioned to discuss in some detail. 
Second, and in a somewhat more speculative mode, what are the possible future trajectories for the form of domestic worker migration described in the book? This is a question that Olivia touches upon early on, but one that perhaps deserves further attention with regard to the questions above and ongoing transformations in Indonesia; notably, the enduring moratorium on sending female migrants to the Middle East and widely publicized claims by the Indonesian president Joko Widodo that the deployment of female domestic workers abroad undermines the country's pride and dignity. Furthermore, the Indonesian economy is growing rapidly - estimated to become the world's fourth largest by 2050-with rising wages and increasing opportunities to find employment within the country. At the same time, the rise of budget airlines in the country and throughout the region has greatly facilitated mobility, as increasing numbers of international flights, not least between secondary cities, have facilitated labour migration and cross-border mobility more generally. Jakarta-Singapore and Jakarta-Kuala Lumpur are now among the busiest international airline routes in the world.

With regard to low-skilled labour migration, it is particularly significant that the infamous terminal for return migrants at Jakarta international airport has closed. This is in part an effect of the moratorium on sending labour migrants to the Middle East, but also because migrants are increasingly returning through a broader range of airports closer to home. The closing of the terminal is symbolically significant, however, since it appears to strike at the very heart of an Indonesian migration regime that has been centred on carefully controlling mobility. With this in mind, and with regard to the recurring criticisms against domestic-worker migration and the transformations outlined above, the question arises if the migration regime-as Olivia describes it in her book and I have described it in my own work-will in the future be understood as reflecting a specific historical epoch that combined the remaining (perhaps now fading) authoritarian force of Soeharto's New Order with the liberalizing and democratizing forces of the post-1998 regime. Or will the forms of brokerage and state regulation that characterize Olivia's book endure in a new form?

\author{
Johan Lindquist \\ Stockholm University, Stockholm, Sweden \\ johan.lindquist@socant.su.se
}




\section{References}

Altenried, Moritz, Manuela Bojadžijev, Leif Höfler, Sandro Mezzadra, and Mira Wallis (2018). 'Logistical borderscapes: Politics and mediation of mobile labor in Germany after the "summer of migration"', South Atlantic Quarterly 17-2:291-312.

Gammeltoft-Hansen, Thomas and Ninna Nyberg Sørensen (eds) (2013). The migration industry and the commercialization of international migration. London: Routledge.

Kloppenburg, Sanneke (2013). Tracing mobilities regimes: The regulation of drug smuggling and labour migration at two airports in the Netherlands and Indonesia. $[\mathrm{PhD}$ dissertation, University of Amsterdam.]

Lindquist, Johan, Xiang Biao, and Brenda Yeoh (2012). 'Opening the black box of migration: Brokers, the organisation of transnational mobility, and the changing political economy in Asia', Pacific Affairs 85-1:7-20.

McKeown, Adam (2008). Melancholy order: Asian migration and the globalization of borders. New York: Columbia University Press.

Rodriguez, Robyn (2010). Migrants for export: How the Philippines brokers labor to the world. Minneapolis: University of Minnesota Press.

Xiang Biao and Johan Lindquist (2014). 'Migration Infrastructure', International Migration Review 48:S122-S148.

Walters, William (2015). 'Migration, vehicles, and politics: Three theses on viapolitics', European Journal of Social Theory 18:469-88.

\section{Following Domestic Worker Migration through a Crisis of Social Reproduction}

In recent years, the transnational migration of women from Indonesia as paid domestic workers has been given considerable scrutiny, with academics and activists focusing on migrants' varying circumstances in destination countries (Silvey 2004; Yeoh and Huang 2010), on the role of state agencies, brokers, and middlemen in facilitating their movement (Lindquist 2010), and on the impacts of their movement on source-area family arrangements (Graham et al. 2012). As is the case more widely, the debate in Indonesia oscillates between positive and negative views (De Haas 2012). Women's migration is viewed on the one hand as contributing to Indonesia's national development via the remittance of foreign-exchange earnings, aligning with a neoliberal 'migration for development' discourse. On the other hand, public debate in Indonesia and beyond has been particularly attuned to issues of women's vulnerability to abuse and exploitation, along with anxieties about what women's long-term absences imply for their family, their wellbeing, and gendered norms of care. 
Such anxieties are made more acute as they play out across borders and jurisdictions in a context of troubled inter-state relationships between Indonesia and migrant destination countries in Asia and the Middle East.

With this compelling, multi-sited ethnographic study, Olivia Killias 'follows the maid' to explore the everyday practical encounters of various actors (women migrants, their families, recruiters, employers) at the different sites, stages, and moments of a migration process that links rural Javanese women with urban, middle-class homes in Malaysia and that makes villagers into migrant maids. The insights she draws from her observations and interviews are analysed and enriched through careful engagement with some of the key studies that have zoned in on particular dimensions of the care chain in Indonesia, such as Johan Lindquist's work on brokers and brokerage (Lindquist 2010, 2012) and Rachel Silvey's work on immobility, precarity, and debt (Silvey 2007; Silvey and Parreñas 2019). What results is a rich, nuanced, and reflective account that vocalizes the moral, social, and economic dilemmas of women migrants, brokers, trainers, and employers in visceral ways.

For this reader, the wider significance of the study lies in its discussion of how racialized gender ideologies are instrumentalized and reinforced at every step along the way, but particularly in efforts to regularize women's migration through the legal requirement that it is undertaken via private intermediaries that train and broker migrant domestic workers. The study shows how this produces a precarious, transnational working class and constitutes the infrastructure' of contemporary bonded labour, leading Killias to draw a comparison with colonial forms of indentured labour mobilization. Embedded within nascent forms of capitalist enclosure, indentured migrant workers were required to serve the expansion of capitalist production in Indonesia and beyond. In making this comparison, she notes that what distinguishes migration for domestic work is that it concerns 'social reproduction'- the labour that goes into household care work-meaning employers and workers are brought together in particularly intimate ways. However, whilst the author attends closely to the continuities and ruptures between contemporary domestic-worker migration and colonial labour mobilization for production, the emphasis on the relationships that facilitate migration and hold the chain together means that the concept of social reproduction, and its attendant historical continuities and ruptures, is not dealt with centrally.

The concept of social reproduction refers expansively to the activities and relationships directly involved in the daily and intergenerational maintenance of life, labour power, and the social processes connected to caring and socialization. Here, I focus on two related issues that emerge when the reader 'follows the maid' through a social-reproduction conceptual lens and that have implic- 
ations for understanding what underpins this phenomenon and the ongoing challenges for addressing its inherent social injustices. First, underlying this study is a looming acknowledgement of a regional crisis of social reproduction in Southeast Asia, or what Beier (2018) describes as a double enclosure where policies aimed at integrating women into the paid workforce rest on the commodification of social reproduction. Within the book we are offered glimpses of the lives of employers-Nur, a Malay mother of four, and the Chinese-Malaysian employer of Ika — and some discussion of changes in paid domestic service in Malaysia. Notably, we do not hear about the husbands of these employers, nor of the circumstances that led to them 'outsourcing' socialreproduction activities to precarious migrant domestic workers. It might be assumed that employers are themselves subject to processes of gender, class, and racial subjectification, as the Malaysian state's drive to economic competitiveness rests on the increased employment participation rates of educated women but with insufficient state provision of social and welfare services (Elias 2009). This crisis is only resolvable through Southeast Asia's own version of racial capitalism (Bhattacharyya 2018).

Secondly, a regional 'crisis of social reproduction' may underpin the ambivalence that emerges in political responses in Indonesia to the transnational migration of domestic workers, which Olivia Killias describes as being deeply gendered and reflective of paternalistic gender norms. The employment of domestic workers within Indonesia is of greater numerical importance than that of migrant domestic workers and is estimated at 10.5 million compared to around six million working overseas (Ramadhani 2016). Killias notes that the employment of maids by Jakarta's governing elites may account for some of the uneasiness around the issue of transnational domestic-worker migration. However, a deeper analysis of this would imply that in a context where many middle-class and low-income women are incorporated into the workforce and where, amidst prevailing gender norms, there are limited opportunities for family-based care to accommodate this, a crisis of social reproduction may underpin political responses more broadly. Evidence for this emerges in a study by Gastaldi, Jordhus-Lier, and Prabawati (2017), which suggests that there are important contradictions between political activism and the direct material interests of the labour movement, NGO community, academics, and government officials in Indonesia. These groups may be supportive of minimum wages for domestic workers, but they simultaneously express concern that 'this would make domestic service less affordable for working- and middleclass families - themselves included' (Gastaldi, Jordhus-Lier, and Prabawati 2017:167). In other words, at this juncture in Indonesia the care work necessary for challenging exploitative practices and building solidarities through 
activism and academic research is only possible when social reproduction is outsourced. Building from this, it would seem that the social actors present at all the stages and sites of Olivia Killias's multi-sited ethnography are linked together not only through a migrant care chain, but through its structuring in the context of a wider crisis of social reproduction that is deeply embedded in contemporary capitalism and patriarchy, and that is giving rise to devalued and fragmented lives situated amidst multi-dimensional exploitative relations.

\author{
Rebecca Elmhirst \\ University of Brighton, Brighton, UK \\ R.J.Elmhirst@brighton.ac.uk
}

\title{
References
}

Beier, Frederike (2018). 'Marxist perspectives on the global enclosures of social reproduction', tripleC: Communication, Capitalism \& Critique. 16:546-61.

Bhattacharyya, Gargi (2018). Rethinking racial capitalism: Questions of reproduction and survival. London: Rowman and Littlefield International.

Elias, Juanita (2009). 'Gendering liberalisation and labour reform in Malaysia: Fostering "competitiveness" in the productive and reproductive economies', Third World Quarterly 30:469-83.

Gastaldi, Margarita, David Jordhus-Lier, and Debbie Prabawati (2017). 'Domestic workers and their struggle for citizenship and collective identity in Indonesia', in: Eric Hiariej and

Kristian Stokke (eds), Politics of citizenship in Indonesia, pp. 153-76. Jakarta: Yayasan Pustaka Obor Indonesia.

Graham, Elspeth, L.P. Jordan, Brenda S. Yeoh, Theodora Lam, Marla Asis, and Sukamdi (2012). 'Transnational families and the family nexus: Perspectives of Indonesian and Filipino children left behind by migrant parent(s)', Environment and Planning A 44:793-815.

Haas, Hein de (2012). 'The migration and development pendulum: A critical view on research and policy', International Migration 50-3:8-25.

Lindquist, Johan (2010). 'Labour recruitment, circuits of capital and gendered mobility: Reconceptualizing the Indonesian migration industry', Pacific Affairs 83-1:115-32.

Lindquist, Johan (2012). 'The elementary school teacher, the thug and his grandmother: Informal brokers and transnational migration from Indonesia', Pacific Affairs $85^{-}$ 1:69-89.

Ramadhani, Nurul Fitri (2016). 'Domestic workers plead for protection', The Jakarta 
Post, 15-6-2016. https://www.pressreader.com/indonesia/the-jakarta-post/2016o615 /281565175041670 (accessed 19-8-19).

Silvey, Rachel (2004). 'Transnational migration and the gender politics of scale: Indonesian domestic workers in Saudi Arabia', Singapore Journal of Tropical Geography 25-2:141-55.

Silvey, Rachel (2007). 'Unequal borders: Indonesian transnational migrants at immigration control', Geopolitics 12:265-79.

Silvey, Rachel and Rhachel Parreñas (2019). 'Precarity chains: Cycles of domestic worker migration from Southeast Asia to the Middle East', Journal of Ethnic and Migration Studies 46-16:3457-3471.

Yeoh, Brenda S. and Shirlena Huang (2010). 'Transnational domestic workers and the negotiation of mobility and work practices in Singapore's home-spaces', Mobilities $5: 219-36$.

\section{4}

\section{Response by Olivia Killias}

First of all, I would like to thank the Bijdragen tot de Taal-, Land-en Volkenkunde for inviting me to participate in a book debate on Follow the maid, thereby allowing me to engage with scholars whose work I have appreciated for years. Marina de Regt, Johan Lindquist, and Rebecca Elmhirst have all been very generous discussants, and their questions have encouraged me to think about my ethnography in different, broader, and more comparative terms.

In Follow the maid, I explore the moral, social, economic, and legal processes by which Javanese women are turned into 'maids'; their migration to Malaysia, where they work in the intimate spaces of middle-class family homes; and their return to Indonesia years later. ${ }^{1}$

Johan Lindquist has suggested that the Indonesian migration regime that I describe in the book might reflect "a specific historical epoch" of Indonesian

1 A short clarification regarding the term 'maid' may be needed. Marina de Regt has rightly noted that the term is generally considered rather derogatory. I agree with her, and part of the journey of becoming a 'maid' as it is described in the book is a deeply humiliating experience. At the same time, however, the English term 'maid' is the expression most widely used to designate domestic workers in contemporary Malaysia, and in this context its meaning is more ambivalent. In fact, 'maid' stands for 'modern', professionally trained domestic workers and has therefore a rather positive connotation-in contrast to Malay terms of fictive kinship that are now considered inappropriate because of their association with more 'traditional', informal, and unregulated forms of paid domestic service (see pp. 141-42; see also Killias 2014). In the book, I thus use 'maid' as an emic term that allows me to 'convey the local nuances of power that such terms reveal' (Adams and Dickey 2000:9). 
society, and I think that this is a very perceptive interpretation. Lindquist's own work on labour brokerage from Indonesia has revealed the extent to which shifts in the modes of migration mediation have been determined by broader social and political transformations (2019, co-authored with Xiang Biao). In his contribution to this debate, Johan Lindquist has asked me whether the Indonesian case should rather be seen as an 'outlier' or as an 'exemplary model' in terms of international domestic worker migration. In my opinion, Indonesia is both. In fact, today, Indonesia has adopted policies shaped by the global 'migration for development' paradigm, and many of its policies are comparable to those of other, competing labour-sending states, such as the Philippines or Sri Lanka. The idea that migrant domestic workers need to be trained before departure, to take just one example, can also be found in the Filipino 'model' of labour brokerage, and in both the Filipino and the Indonesian cases, these trainings instil qualities of docility and submissiveness in women migrants (see, for instance, Debonneville and Killias 2019). At the same time, attentiveness to the material details of migrants' journeys (see Walters 2015) reveals telling differences with the Philippines: In Indonesia, these trainings take place in secluded camps. The practice of immobilisation in camps brings to light a longer-standing concern with the control over (mobile) women workers' bodies that is reminiscent of the military regime of the New Order. In my view, the contemporary Indonesian migration regime can best be understood as an assemblage of global 'migration for development' policies, the legacy of colonial forms of labour mobilization, the authoritarian remainder of Soeharto's New Order, and the decentralizing impetus of post-1998 politics.

Although my book concentrates more on Indonesia, I agree with Marina de Regt that it is instructive to think about the extent to which the Malaysian context shapes the experiences of Indonesian migrant women in specific - and maybe distinct - ways in comparison to other destination countries, such as Taiwan or Saudi Arabia. As I explain in the book, Malaysia is considered a good 'first' destination, among other things because of its geographical proximity. There is a long-standing history of trade and exchange between the contemporary neighbouring nation-states of Indonesia and Malaysia. Consequently, when they arrive at the airport in Kuala Lumpur, Indonesian migrant domestic workers arrive in a place where many other Indonesians have lived and worked, where Malay is the national language, and where Islam is the official religion. However, during the past twenty years, there has been a marked increase in the policing of territorial borders, a stricter regulation of immigration from Indonesia to Malaysia, and the deportation of hundreds of thousands of illegal Indonesian migrant workers from Malaysia (Spaan, Van Naerssen, and Kohl 2002). In this process, Indonesian migrant workers have been more and more 
portrayed as foreign 'aliens' in Malaysian public discourse, and the presence of Indonesian women in the most intimate spaces of Malaysian societynamely, middle-class family homes - has led to widespread moral panics (see Killias 2014, 2018). I think that it is therefore important not to assume that Malaysia is automatically 'culturally [...] much closer' (De Regt) to Indonesian migrant domestic workers. Moreover, beyond the legal, political, and cultural contexts of receiving countries, the specific experience of any domestic worker is very much shaped by the requirements of her individual employers (Hess 2005). This is particularly noteworthy because Indonesian domestic workers have to live in with their employers and because their mobility beyond the latter's homes tends to be very limited-be it in Malaysia, Singapore, Taiwan, or Saudi Arabia. As my conversations with Javanese women who have returned from working abroad illustrate, 'proximity' can be differently constructed. A Javanese domestic worker does not necessarily feel 'closer' to a Chinese Malaysian family speaking Hokkien, eating pork, and owning a dog in Kuala Lumpur than a Saudi family speaking Arabic, eating halal food, and celebrating Ramadan in Riyadh (or vice versa). Ultimately, what characterizes paid domestic service for Indonesian women in the many different contexts that they work in, is a tension so well-described by Sara Dickey (2000) between, on the one hand, the intimacy brought about by the fact that the domestic worker is living under one roof with her employers, and, on the other hand, the distance between them, based on class, religious, ethnic, national, or other forms of belonging.

Stressing the important fact that employers of domestic workers are themselves formed by processes of gender, class, and racial subjugation, Rebecca Elmhirst proposes to use the concept of 'social reproduction' to analytically explore the ways in which the lives of those who are employing domestic workers in various locations, in Indonesia and in Malaysia, are intertwined. Discussing the notion of 'social reproduction' in more depth is indeed a promising idea, especially when linking this discussion to the question of the organization of labour. In the current context of transnational care chains, the burden of social reproduction is made to be born exclusively by workers and workers' left-behind families: Indonesian domestic workers in Malaysia are recruited in the prime of their lives (age limit: 35), they are not allowed to bring along their children, pregnancy leads to deportation, and as soon as they get seriously ill, they are sent home. In many cases, the migrant women themselves are not able to attend to illnesses or even deaths of family members back in Java. This complete avoidance of responsibility for domestic workers' social reproduction, inscribed in the Malaysian labour migration regime, does not seem possible to the same extent in domestic service within Indonesia, as some of my eth- 
nographic data illustrate (employers, at least historically, have partly taken up responsibility for the social reproduction of their domestic workers; see pp. $73^{-}$ 4).

While the concept of social reproduction is relevant, I believe that there are two caveats with the term 'crisis'. First, calling the current situation a 'crisis' might obscure the historical continuities in the organization of social reproduction. In Malaysia, the public debate about domestic workers has long been dominated by a sense of 'crisis', as newspaper headlines from the early 1980s aptly illustrate (Armstrong 199o). Secondly, and more importantly, when we define the question of paid domestic service exclusively as a 'crisis of social reproduction', we might overlook the complexities of the so-called 'need' for domestic workers (Anderson 2006). In fact, scholars have shown that the demand for privatized domestic work cannot simply be explained by higher employment rates for women, combined with a lack of state provision of childcare or care for the elderly (Anderson 2006). In Doméstica, Pierrette Hondagneu-Sotelo has argued that even where affordable childcare centres exist, many middle-class Americans prefer to employ a nanny: privatized domestic work taking place in employers' homes gives the latter more control and flexibility, and it often makes it possible to have cleaning and care work done by the same person (Hondagneu-Sotelo 2007:5). This solution is also one that many Malaysian employers prefer. Nur, a Malaysian mother of four who is also mentioned in the book, explained to me that she decided to take her children out of day care after only five months, most importantly because nobody took care of the housework: 'So then you have to sit up late to do it all, and then you don't get enough rest, oh no, no, no ... I think it is better to have somebody at home.' She then recruited an Indonesian domestic worker. Another young Malaysian mother whom I interviewed in Kuala Lumpur explained that the fact that she had taken a domestic worker had been the result of pressures from her environment. Having initially sent her children to a creche, while taking care of the household chores herself, she was constantly urged by her in-laws to 'just take a maid', and her husband, watching her clean the bathroom, told her that she should be 'doing something else.' Hence, we cannot explain the 'demand' for migrant domestic workers by exclusively pointing to the lack of child- and elderly care institutions, and we have to attend to issues of middle-class identity and status as well—or, as Bridget Anderson (2003:105) puts it, to the lifestyles made possible by the labour of paid domestic workers. In Malaysia and Indonesia, employing a paid domestic worker has become key 'in the construction of middle-class identity and status' (Huang, Yeoh, and Abdul Rahman 2005:2; Chin 1998). As my ethnographic data illustrate, many domestic workers employed in middle-class households are 'cleaners rather 
than carers', to cite Anderson again (2003). They allow their employers' families to take up lifestyles the latter would otherwise not be able to sustain. As Anderson puts it, 'ironed clothes, dust-gathering ornaments, polished floors, and clean windows are not necessities; but such markers affirm a household's status by displaying its access to financial and human resources' (Anderson 2003:105). Consequently, when discussing the wider implications of the migration of domestic workers from the perspectives of those who employ them, I think it is important not to forget that the reproduction of social status is also at stake. ${ }^{2}$

On another note, Marina de Regt has asked me to say more about what she calls the 'post-migration phase', after migrant women return from abroad-but the question is whether we can call it 'post-migration' at all. In fact, when returning from overseas, many women find that problems of underemployment and unemployment in the village remain, and job security is practically inexistent: work is temporary and unsteady, and wages are low. When I last met her in 2016, Elia, for instance, a returnee from Malaysia, was working on the new rubber plantation as a day labourer, doing 'man's work', as she put it, that is, the heavy, dirty and dangerous work of tapping rubber trees in the middle of the night. Her wages were far from allowing her to make a living, and she had no security regarding the length of her employment. Accordingly, after their return, women are 'free' to sell their own labour power in the village, most notably on the local plantation, but this 'freedom' comes at a price. One key advantage of indentured or 'unfree' labour, as Indonesian women experience it in Malaysia, is job security: as they sign up for two-year contracts abroad, they know that they will have work and a constant income during these two years. ${ }^{3}$ Consequently, many women decide to migrate again, as long as they still can.

The fact that many returned migrants leave the village again, often within months, has partly led to a sense of disenchantment in the village (p. 197). At the same time, however, the Indonesian economy more broadly has been prospering in recent years, as Johan Lindquist has rightly pointed out, and more and more villagers are now leaving to work in larger cities within Indonesia. Take the case of Elia's daughter, Ipsah, for example, a young woman who has worked both in Malaysia and Singapore. In 2016, Ipsah was living in Jakarta with her

2 Kathryn Robinson (2000) has made a similar argument for the employment of Indonesian domestic workers in Saudi Arabia, where, in many cases, female employers are often not employed in the formal labour market.

3 For an in-depth discussion of the 'excess of market freedom' that plantation workers in Indonesia experience today, see $\mathrm{Li} 2017$. 
husband, in a small compound close to a rubbish dump. While she was working as a domestic worker for a middle-class family during the day, in the early hours of the morning, she and her husband were sorting rubbish at the dump to make additional money. With little prospects for work back in the village in northern Central Java, Ipsah was planning on permanently bringing her mother and her father over to Jakarta, thus providing for her ageing — but still labouring parents.

Ipsah's choice of living in Jakarta illustrates some of the developments that I have touched upon in the book, and that can be interpreted as a possible future trajectory of the contemporary migration regime that Johan Lindquist has asked me about. The fact that Ipsah is employed by an Indonesian middleclass family in the capital seems to indicate, for instance, that employment as a domestic worker within Indonesia is not merely seen as a rite of passage into adulthood any longer (see pp. 69-74), but instead as a long-term strategy, also for older women who have gathered work experience abroad. At the same time, the precarious conditions of women like Ipsah and her mother Elia also point to the downside of Indonesia's economic success story.

As I wrote in the book, when I met him in 2016, Supomo, one of the most successful brokers in the region of Kalembah, proudly showed me the catalogue of an ILO-sponsored programme in which he now participates, recruiting women to work as contract domestic workers across Indonesia (see p. 204). Hence, one possible future trajectory of the contemporary domestic-worker migration regime from Indonesia could be the further formalization of domestic service within Indonesia. Undeniably, the current transformations of paid domestic service in Indonesia-involving much-higher numbers of domestic workers than the overseas labour market, as Rebecca Elmhirst has rightly pointed outdeserve further ethnographic research. I very much hope to be able to contribute to this scholarship in the coming years.

\section{Olivia Killias}

University of Zürich, Zürich, Switzerland olivia.killias@uzh.ch 


\section{References}

Adams, Kathleen M. and Sara Dickey (eds) (2000). Home and hegemony: Domestic service and identity politics in South and Southeast Asia. Ann Arbor: University of Michigan Press.

Anderson, Bridget (2000). Doing the dirty work? The global politics of domestic labour. London: Zed Books.

Anderson, Bridget (2003). 'Just another job? The commodification of domestic labor', in: Barbara Ehrenreich and Arlie R. Hochschild (eds), Globalwoman: Nannies, maids, and sex workers in the new economy, pp. 104-14. New York: Metropolitan Books.

Anderson, Bridget (2006). 'A very private business'. Oxford: Centre on Migration, Policy and Society. [Working Paper 28.]

Armstrong, M. Jocelyn (1990). 'Female household workers in industrializing Malaysia', in: Roger Sanjek and Shellee Cohen (eds), At work in homes: Household workers in world perspective, pp. 146-63. Washington, DC: American Anthropological Association.

Chin, Christine (1998). In service and servitude: Foreign female domestic workers and the Malaysian 'modernity' project. New York: Columbia University Press.

Debonneville, Julien and Olivia Killias (2019). “'À votre service!” La fabrication de la domesticité en Asie du Sud-Est', Moussons 33:109-32.

Dickey, Sara (2000). 'Permeable homes: Domestic service, household space, and the vulnerability of class boundaries in urban India', American Ethnologist 27-2:462-89.

Hess, Sabine (2005). Globalisierte Hausarbeit: Au-pair als Migrationsstrategie von Frauen aus Osteuropa. Berlin: Springer-Verlag.

Hondagneu-Sotelo, Pierrette (2001). Doméstica: Immigrant women cleaning in the shadows of affluence. Berkeley: University of California Press.

Huang, Shirlena, Brenda S.A. Yeoh, and Noor Abdul Rahman (eds) (2005). Asian women as transnational domestic workers. Singapore: Marshall Cavendish Academic.

Killias, Olivia (2014). 'Intimate encounters: The ambiguities of belonging in the transnational migration of Indonesian domestic workers to Malaysia', Citizenship Studies 18-8:885-99.

Li, Tania (2017). 'The price of un/freedom: Indonesia's colonial and contemporary plantation labor regimes', Comparative Studies in Society and History 59-2:245-76.

Lindquist, Johan and Xiang Biao (2019). 'Space of mediation: Labour migration, intermediaries and the state in Indonesia and China since the nineteenth century', Revue européenne des migrations internationales 1-35:39-62.

Robinson, Kathryn (2000). 'Gender, Islam and nationality', in: Kathleen M. Adams and Sara Dickey (eds), Home and hegemony:Domestic service and identity politics in South and Southeast Asia, pp. 249-83. Ann Arbor: University of Michigan Press. 